\title{
EFFECT OF PLYOMETRIC TRAINING PROGRAM ON ATHLETIC PERFORMANCE IN YOUNG TAEKWONDO ATHLETES
}

\author{
Fatih Ahmet Genç, \\ Önder Dağlığlu ${ }^{\mathrm{i}}$ \\ Gaziantep University, \\ Physical Education and Sport Faculty, \\ Gaziantep, Turkey
}

\begin{abstract}
:
The aim of this study is to examine the effect of plyometric training program on athletic performance in young male taekwondo players. 20 volunteer male taekwondo athletes between the ages of 17-22 who regularly practice taekwondo participated in our study. Two different groups were formed as 10 athletes as experimental group and 10 athletes as control group. A plyometric training program was applied to the experimental group 3 days a week for 8 weeks. During the study, both groups continued their normal taekwondo training. The subjects were explained in detail how the study would be carried out. During the study, they were asked not to use diet or nutritional supplements and not to do separate exercises. The body weight, height, body mass index (BMI), body fat percentage (BFP), anaerobic power, back strength, hand grip strength, speed and flexibility values of the participating athletes were measured before starting the plyometric training program and after the training was completed. SPSS 22.0 program was used for statistical analysis. Paired Samples T-Test was used for in-group comparisons. Statistical results were evaluated at $\mathrm{p}<0.05$ significance levels. Anaerobic power, BFP, vertical jump, back strength, hand grip strength right, hand grip strength left, speed and flexibility values of the experimental group were found to be significant at $p<0.05$ level. Only flexibility values of the control group were found to be significant at $\mathrm{p}<0.05$ level. As a result, it can be said that the 8 -week plyometric training program has a positive effect on the athletic performance of taekwondo athletes.
\end{abstract}

Keywords: plyometric training, athletic performance, Taekwondo

'Correspondence: email daglioglu@hotmail.com 


\section{Introduction}

The fact that sports branches are carried out professionally nowadays has increased the performance expectations and success concerns of the athletes. Trainers create many training methods to contribute to the targeted development of their athletes and increase their athletic performance and benefit from training sciences in this direction. Plyometric training is one of the indispensable training methods that affects success and improves physical performance (1). Taekwondo, a very popular martial arts sport, is an activity that requires many skills, high energy demands and sophisticated techniques. Therefore, technical and intense physical exercises should be included in the training program. Technical training relies on specific training, such as classical exercises like running, stretching, jumping rope or hitting a racket. To train well, it is essential to know the metabolic demands involved in this type of exercise $(2,3,4,5)$.

Previous research has shown that the movement time of the Taekwondo stroke is 0.22-0.31 seconds, with a maximum stroke rate of 22.4 milliseconds (6). These features have shown that Taekwondo is an "explosive" sport and developing good training programs for the explosive power of the lower extremity is the key to improving Taekwondo performance. Plyometric, developed by Veroshanski in 1991, has been one of the effective methods for training power ability (7). For this reason, it is necessary to include plyometric exercises in the training programs in the taekwondo training period. With this study, it was thought that higher efficiency could be achieved in the athletic performance of taekwondo athletes. It is aimed to reveal the effect of plyometric training program on athletic performance in young male taekwondo players, and to make suggestions to trainers and athletes about training and training planning in this direction.

\section{Methods}

\subsection{Subjects}

20 volunteer male taekwondo athletes between the ages of 17-22, who regularly practice taekwondo, participated in our study. Two different groups were formed as 10 athletes as experimental group and 10 athletes as control group. A plyometric training program was applied to the experimental group 3 days a week for 8 weeks. During the study, both groups continued their normal taekwondo training. The subjects were explained in detail how the study would be carried out. During the study, they were asked not to use diet or nutritional supplements and not to do separate exercises.

\subsection{Study Protocol}

Body weight, height, body mass index (BMI), body fat percentage (BFP), anaerobic power, back strength, right and left hand grip strength, speed and flexibility values of the participating athletes were measured before starting the plyometric training program and after the training was over. In addition to taekwondo training, exercises known as drop jump, box jump, squat jump, split squat jump, overhead slam and plyometric push- 
ups were applied to the plyometric training group. Height, weight and BMI measurements were taken. BFP measurements were determined using the "Holtain skinfold caliper" according to the Jackson/Pollock7 method. The vertical jump test was used for anaerobic power measurement. Flexibility Test (Sit and Reach) and speed test (30 m) were applied.

\subsection{Plyometric Training Program}

In addition to Taekwondo training in the experimental group, 4 weeks at moderate intensity ( 3 sets $x 10$ repetitions and 90 seconds rest) for 4 weeks at high intensity (4 sets $x 10$ repetitions and 90 seconds rest) for both lower and upper extremities for 3 days of a week, a total of 8 weeks plyometric training program was applied. The athletes were told that each exercise movement should be performed at the maximum level and landed smoothly on the floor after the jump movements. Participants were warned not to do any exercises other than taekwondo training and plyometric training in accordance with our plans. Athletic performance measurements were taken 1 day before the start of plyometric training and 1 day after the end of the training.

\subsection{Body Fat Percentage Measurement}

Body fat percentage measurement of 7 distinct areas (chest, midaxillary, abdominal, suprailiac, thigh, subscapula, and triceps) capable of measuring with an accuracy of skinfold thickness $1 \mathrm{~mm}$ received skinfold caliper (Holtain) and the collected data was measured in cm using the Jackson/Pollock 7" body fat percentage value has been reached by applying the formula (8).

\subsection{0 meter Speed Test}

Warm-up and stretching were requested before the athletes were taken for the test. They have taken short sprints in preparation. After that, the start and finish lines were determined and the athletes who were tested $1 \mathrm{~m}$ behind the line were asked to exit when they felt ready. Between trials, the athletes rested for 5 minutes. 2 repetitions were applied to the athletes $(9,10)$. The athlete's time to finish the course was determined by a stopwatch and recorded in the athlete information form in seconds. At the end of the measurement, both grades were taken into account and the best grades were selected for evaluation.

\subsection{Vertical Jump Test-Anaerobic Power}

Athletes were tied from the abdominal region with TAKEI brand jump meter. It was asked to fall into the field while jumping and falling with double legs vertically in a free position with arms over a certain area. Two trials were made and the best high value was recorded as $\mathrm{cm}$. The following formula of Levis was used to calculate anaerobic power. 


\subsection{Back Strength}

The back strength measurement of the athletes was made with the Back-D (Back Strength Dynamometer) back dynamometer, which measures $0-250 \mathrm{~kg}$ of force. Athletes were measured by standing on the dynamometer, with their arms tense without bending them, holding the force arm in a 90 degree bent position and using only their back muscles. The measurement was applied to each athlete twice and the best result was recorded (9).

\subsection{Flexibility Measurements}

Flexibility was measured using a sit and reach table. In practice, the subject to be measured sat on the ground and rested the sole of his bare feet flat on the test table. Subject bent forward from his torso (waist and hip) and reached forward as far as he could without bending his knees, with his hands in front of his body. In order for the test values to be recorded correctly, the subject was asked to wait 1-2 seconds at the furthest point they can reach, without leaning forward or backward. During the test, he stood next to the subject and prevented the athlete from bending his knees. The test was repeated twice and the higher value was recorded.

\subsection{Hand Grip Strength Measurement}

While measuring, the athlete was brought to a standing upright position and the dynamometer was adjusted according to the hand size of the subject. The maximum grip strength was measured on the side, starting with the right hand, with the subject's arm perpendicular and making an angle of 10-15 degrees from the shoulder. The subject did 4 repetitions with his right and left hand and the best grade was recorded.

\subsection{Statistical Analysis}

SPSS statistical program (SPSS for Windows, version 20.0, SPSS Inc. Chicago, Illinois, USA) was used in the analysis of the data obtained from our study. Paired Samples TTest was used for in-group comparisons. Statistical results were evaluated at $p<0.05$ significance levels.

\section{Results}

Table 1: Average Age Table of Participants

\begin{tabular}{|l|l|c|c|}
\hline \multirow{3}{*}{ Age } & & $N$ & Mean \pm SD \\
\cline { 2 - 4 } & Experiment & 10 & $20.10 \pm 1.66$ \\
\cline { 2 - 4 } & Control & 10 & $20.40 \pm 1.71$ \\
\hline
\end{tabular}

When Table 1 is examined, the mean age values of the participants were determined as $20.10 \pm 1.66$ years in the experimental group and $20.40 \pm 1.71$ years in the control group. 
Table 2: Average Height Table of Participants

\begin{tabular}{|l|l|c|c|}
\hline \multirow{3}{*}{ Height } & & $\boldsymbol{N}$ & Mean \pm SD \\
\cline { 2 - 4 } & Experiment & 10 & $173.70 \pm 7.07$ \\
\cline { 2 - 4 } & Control & 10 & $171.40 \pm 5.17$ \\
\hline
\end{tabular}

When Table 2 is examined, the average height values of the participants were determined as $173.70 \pm 7.07 \mathrm{~cm}$ in the experimental group and $171.40 \pm 5.17 \mathrm{~cm}$ in the control group.

Table 3: Weight Average Table of Participants

\begin{tabular}{|l|l|c|c|c|}
\hline \multirow{2}{*}{ Weight } & \multirow{2}{*}{$\boldsymbol{N}$} & \multicolumn{2}{|c|}{ Group } \\
\cline { 4 - 5 } & & & Experiment Mean \pm SD & Control Mean \pm SD \\
\hline \multirow{3}{*}{} & Pre-Test & 20 & $65.65 \pm 11.36$ & $65.90 \pm 7.55$ \\
\cline { 2 - 5 } & Post- Test & 20 & $65.05 \pm 9.62$ & $65.92 \pm 7.04$ \\
\hline
\end{tabular}

When Table 3 is examined, the mean weight values of the participants in the experimental group pretest $65.65 \pm 11.36 \mathrm{~kg}$, post-test $65.05 \pm 9.62 \mathrm{~kg}$, control group pre-test $65.90 \pm 7.55$ $\mathrm{kg}$, post-test $65.92 \pm 7.04 \mathrm{~kg}$.

Table 4: Experimental Group Pre-test Post-test Measurement Results

\begin{tabular}{|l|c|c|c|c|c|}
\hline \multirow{2}{*}{ Variable } & Pre-test & Post-test & \multirow{2}{*}{ df } & $\mathbf{t}$ & $\mathbf{p}$ \\
\cline { 2 - 6 } & Mean \pm SD & Mean \pm SD & & & \\
\hline Weight & $65.65 \pm 11.36$ & $65.05 \pm 9.61$ & 9 & 0.814 & 0.437 \\
\hline BMI $\left(\mathrm{kg} / \mathrm{m}^{2}\right)$ & $21.94 \pm 2.91$ & $21.67 \pm 2.29$ & 9 & 1.218 & 0.254 \\
\hline BFP $(\%)$ & $10.09 \pm 4.62$ & $9.81 \pm 4.39$ & 9 & 3.487 & $\mathbf{0 . 0 0 7}$ \\
\hline Anaerobic power $(\mathrm{kgm} / \mathrm{sn})$ & $949.10 \pm 199.22$ & $1010.90 \pm 183.45$ & 9 & -5.326 & $\mathbf{0 . 0 0 0}$ \\
\hline Vertical Jump $(\mathrm{cm})$ & $45.10 \pm 6.78$ & $51.90 \pm 6.65$ & 9 & -17.493 & $\mathbf{0 . 0 0 0}$ \\
\hline Back strength $(\mathrm{kg})$ & $116.40 \pm 16.50$ & $124.20 \pm 15.43$ & 9 & -6.882 & $\mathbf{0 . 0 0 0}$ \\
\hline Hand grip strength right $(\mathrm{kg})$ & $41.30 \pm 5.10$ & $46.19 \pm 5.06$ & 9 & -33.753 & $\mathbf{0 . 0 0 0}$ \\
\hline Hnad grip strength left $(\mathrm{kg})$ & $37.30 \pm 5.49$ & $40.50 \pm 5.44$ & 9 & -24.000 & $\mathbf{0 . 0 0 0}$ \\
\hline Speed 30m $(\mathrm{sn})$ & $5.27 \pm 0.23$ & $5.19 \pm 0.19$ & 9 & 4.879 & $\mathbf{0 . 0 0 1}$ \\
\hline Flexibility $(\mathrm{cm})$ & $35.40 \pm 6.11$ & $39.70 \pm 6.01$ & 9 & -12.836 & $\mathbf{0 . 0 0 0}$ \\
\hline
\end{tabular}
${ }^{*} \mathrm{p}<0.05$

In Table 4, the comparison of the pre-test and post-test measurement values of the experimental group in line with the data obtained after the plyometric training program is given. Anaerobic power, BFP, vertical jump, back strength, hand grip strength right, hand grip strength left, speed and flexibility values of the experimental group were found to be significant at $\mathrm{p}<0.05$ level. No significant difference was found in the other weight and BMI data of the experimental group $(\mathrm{p}>0.05)$. 
Table 5: Analysis of the Pretest-posttest Data of the Control Group

\begin{tabular}{|l|c|c|c|c|c|}
\hline \multirow{2}{*}{ Variable } & Pre-Test & Post-Test & \multirow{2}{*}{ df } & $\mathbf{t}$ & $\mathbf{p}$ \\
\cline { 2 - 6 } & Mean \pm SD & Mean \pm SD & & & \\
\hline Weight & $65.90 \pm 7.54$ & $65.92 \pm 7.03$ & 9 & -.073 & 0.944 \\
\hline BMI $\left(\mathrm{kg} / \mathrm{m}^{2}\right)$ & $22.35 \pm 2.17$ & $22.23 \pm 2.08$ & 9 & .859 & 0.412 \\
\hline BFP $(\%)$ & $10.28 \pm 2.54$ & $10.21 \pm 2.52$ & 9 & 1.836 & 0.100 \\
\hline Anaerobic power $(\mathrm{kgm} / \mathrm{sn})$ & $924.80 \pm 140.09$ & $926.50 \pm 135.46$ & 9 & -.419 & 0.685 \\
\hline Vertical Jump $(\mathrm{cm})$ & $42.40 \pm 6.29$ & $42.60 \pm 6.38$ & 9 & -1.500 & 0.168 \\
\hline Back strength(kg) & $110.50 \pm 17.72$ & $110.60 \pm 17.76$ & 9 & -.361 & 0.726 \\
\hline Hand grip strength right $(\mathrm{kg})$ & $41.30 \pm 8.68$ & $41.60 \pm 7.44$ & 9 & -.669 & 0.520 \\
\hline Hand grip strength left $(\mathrm{kg})$ & $36.40 \pm 8.61$ & $37.70 \pm 8.91$ & 9 & -1.041 & 0.325 \\
\hline Speed 30 m $(\mathrm{sn})$ & $5.57 \pm 0.53$ & $5.56 \pm 0.52$ & 9 & 1.672 & 0.129 \\
\hline Flexibility $(\mathrm{cm})$ & $30.90 \pm 6.70$ & $32.00 \pm 6.46$ & 9 & -3.973 & $\mathbf{0 . 0 0 3}$ \\
\hline
\end{tabular}

${ }^{*} \mathrm{p}<0.05$

The comparison of the pre-test and post-test measurement values of the control group is given in Table 5. Only flexibility values of the control group were found to be significant at $p<0.05$ level. Anaerobic power, vertical jump, back strength, right hand grip strength, left hand grip strength and speed data of the control group were not significant $(\mathrm{p}>0.05)$.

\section{Discussion}

In this study, it was found that there was a $p<0.05$ significance in anaerobic power, vertical jump, back strength, hand grip strength right, hand grip strength left, speed and flexibility values after the plyometric training program of the experimental group. There was no significant difference in the other weight, BMI and BFP data values of the experimental group ( $p>0.05$ ). According to the pre-test and final test of the control group, there was a significant difference at the $p<0.05$ level only in the flexibility values of the control group. There was no significant difference between anaerobic power, vertical jump, back strength, hand grip strength right, hand grip strength left and speed data of the control group $(\mathrm{p}>0.05)$.

Although the need for strength is different in sports branches, strength comes to the fore when the motoric properties are fully effective. Especially during the competition, force plays an important role in ensuring the best level of fast movement and jump. Plyometric training applications are used in the development of strength, which is one of the most important components of sporting success, in a short time. These exercises that provide physical development are known as jump exercises in the literature and studies show that they make a very important contribution to jump performance (11). It is stated that plyometric exercises will effectively improve vertical jump performance, which is very important for athletic performance $(12,13)$.

In a study conducted on young handball players, a significant difference in vertical jump values was found after a plyometric training program applied for 8 weeks. It is said that this significance is due to the fact that jumps in plyometric training are applied explosively in a very short period of time and, accordingly, both explosive power and 
explosive property develop (14). It was observed that another 6-week plyometric training study conducted on Taekwondo athletes showed significant increases in agility, vertical jump height and peak torque ratio values (15). The studies in the literature support our result of the increase in vertical jump and anaerobic power data as a result of the 8-week training we had in the experimental group.

When the pre-test and post-test data of the experimental group as a result of the 8-week plyometric training application performed in our study were compared, statistical significance was found at the $\mathrm{p}<0.05$ level in the speed values, but no significant difference was found in the control group. When the literature on the effect of plyometric training on $30 \mathrm{~m}$ sprint values was examined, a study in which a 2-month strength and plyometric training program was applied to athletes found a significant difference between 30 m sprint tests (16), similarly in young volleyball players (17), football players (18), in volleyball players (19), $30 \mathrm{~m}$. He states that it increases his sprinting ability. Therefore, $30 \mathrm{~m}$. speed findings are in parallel with the literature. From this point of view, it can be said that plyometric training contributes to the development of the speed qualities of the athletes. This can be attributed to the fact that plyometric exercises improve the elongation-shortening cycle of the muscle.

After 8 weeks of plyometric training, there was a statistically significant difference in the back strength values of the experimental group at the level of $p<0.05$, while there was no significant difference in the control group. Similarly, in a study examining the effects of plyometric exercises on vertical jump levels and physical and physiological parameters on basketball players; When evaluated together with the control group, a significant increase was found in the vertical jump level and back strength in the experimental group (20). It has been observed that the study finding on the subject in the literature is in parallel with the current study finding. After 8 weeks of plyometric training, application performed in our study, statistical significance was found at the $\mathrm{p}<0.05$ level in the flexibility values of both the experimental group and the control group. It is thought that the improvement in the control group depends on the taekwondo trainings that continue throughout the process. In a study conducted with football players in the 16-18 age group, it was concluded that 10-week plyometric exercises positively affected flexibility and anaerobic power capacity (21). In another study, it was determined that the flexibility of the athletes who underwent 8-week plyometric training was higher than the control group (22). It has been observed that the findings of the studies on the subject in the literature are similar to the findings of the current study.

A statistical significance was found at the $p<0.05$ level in the right and left hand grip strength values of the experimental group after the plyometric training. No significant difference was observed in the control group. It has been observed that the findings of the studies on the subject in the literature are similar to the findings of the current study we have done $(23,24)$.

In our study, after 8 weeks of plyometric training applied to the experimental group, significant difference was found in the BFP values because of the decrease in fat rate $(\mathrm{p}<0.05)$. In the control group, no significance was found in the BFP values. In the 
literature, it is stated that there is a decrease in BFP after physical activities $(25,26)$. In another study, a significant decrease was found in body fat percentage as a result of the regular plyometric training program applied to male basketball players in the 14-15 age group (20). In our study, there was a difference between the pre-test and post-test data of the experimental group, as well as the decrease in body fat percentage was higher than the control group. It is thought that the reason for this is the effect of taekwondo training applied together with plyometric training, reducing body fat percentage and increasing the muscle rate of the body.

As a result of our research, it is thought that the developed plyometric training program applied to young Taekwondo athletes in addition to Taekwondo training has a positive effect on athletic performance. Since plyometric training applied regularly and in a planned manner will have a positive effect on athletic performance, it may be recommended to include plyometric training in the Taekwondo training plan.

\section{Conflict of Interest Statement}

There are no potential conflicts of interest between authors of this article.

\section{About the Authors}

Fatih Ahmet Genç is a graduate student at Gaziantep University, Faculty of Sport Sciences, Turkey. This study is a part of Fatih Ahmet Genç's master thesis.

Önder Dağlığlu is a professor at the faculty of sport sciences at Gaziantep University, Turkey.

\section{References}

1. L. National Basketball Conditioning Coaches Association. NBA Power Conditioning. USA: Human Kinetics, 1997

2. Heller J, Peric T, Dlouha R, Kohlikova E, Melichna J, Vakova H. Physiological profiles of. male and female TKD black belt. J Sports Sci 1998;16:243-9

3. Melhim AF. Aerobic and anaerobic power responses to the practice of Taekwondo. Br J Sports Med 2001;35:231-5.

4. Thompson WR, Vinueza C. Physiological profiles of male and female Taekwondo black belts. Sports Medicine and Training Rehabilitation 1991;3:49-53

5. E. Bouhlel, A. Jouini, N. Gmada, A. Nefzi, K. Ben Abdallah, Z. Tabka, Heart rate and blood lactate responses during Taekwondo training and competition, Science \& Sports, Volume 21, Issue 5, 2006,

6. Cho, K. M. (1996). The kinetic analysis of taekwondo attack movement. Unpublished masters thesis, National College of Physical Education and Sports.

7. Tsai, Y. J., Liu, G. C., Chen, C. Y., \& Huang, C. (1999). The effect of different plyometricsquat training on Taekwondo power development in the lower extremity. In ISBSConference Proceedings Archive 
8. http://www.linear-software.com/online.html Access Date: 05.10.2021

9. Tamer, K., Sporda Fiziksel-Fizyolojik Performansının ölçülmesi ve Değerlendirilmesi. Türkerler Kitabevi, Ankara, 1995.

10. Hermassi S., Chelly MS., Tabka Z., Shephard RJ., Chamari K. Effects of 8 Weeks in Season Upper and Lower Limb Heavy Resistance Training on The Peak Power, Throwing Velocity, and Sprint Performance of Elite Male Handball Players. The Journal of Strength and Conditioning Research. 2011; 25(9). 2424-2433

11. Yüksel Y, Hekim M, Tokgöz M, Zengin S, Ulukan H, KayaE, 2016. Adolesan dönemde bulunan sporcularda pliometrik antrenman. Journal of Human Sciences, 13, 56025612.

12. Hoare D, 2003. Predicting success in junior elite basketball players-the contribution of anthropometric and physiological attributes. Am Journal of Sports Medicine, 60, 56.

13. Martinez EB, Sanchez AJL, Fresno DBD, Lopez EJ, 2011. Effects of combined electrostimulation and plyometric training on vertical jump and speed tests, Journal of Human Sport and Exercise, 6, 603.

14. Pancar, Z., Biçer, M., \& Özdal, M. (2018). 12-14 Yaş Grubu Bayan Hentbolculara Uygulanan 8 Haftalik Pliometrik Antrenmanlarin Seçilmiş Bazi Kuvvet Parametrelerine Etkisi. Spor Ve Performans Araştırmaları Dergisi, 9(1), 18-24.

15. Singh, A., Boyat, A. V., \& Sandhu, J. S. (2015). Effect of a 6 week plyometric training program on agility, vertical jump height and peak torque ratio of Indian Taekwondo players. Sport Exerc Med Open J, 1(2), 42-46.

16. Özdemir S. 14-16 yaş grubu erkek futbolcularda kompleks antrenman programının patlayıcı güç, kuvvet, sürat ve çeviklik gelişimine etkisi. Marmara Üniversitesi Sağlık Bilimleri Enstitüsü, Yüksek Lisans Tezi, İstanbul, (Tez Danışmanı: Yrd. Doç. Dr. Ali K1z1let), 2009.

17. Topuz, F. Özel Pliometrik Çalışmaların Genç Voleybolcuların Bacak Güç Gelişimine Etkisi. 2008. Yüksek Lisans Tezi: Kırıkkale Üniversitesi; (Prof. Dr. Mehmet Kutlu).

18. Lim, J. H., Wee, E. H., Chan, K. Q., and Ler, H.Y. (2012). Effect of Plyometric Training on the Agility of Students Enrolled in Required College Badminton Programme, International Journal of Applied Sports Sciences Vol. 24, No. 1, 18-24.

19. Yıldırım T. Liseli Erkek Voleybolcularda Sekiz Haftalık Pliometrik Antrenman Programının Seçilmiş Fiziksel ve Fizyolojik Parametreler Üzerine Etkisi. 2010. Yüksek Lisans Tezi. Konya: Selçuk Üniversitesi; (Yrd. Doç. Dr. Turgut Kaplan)

20. Cicioğlu İ. Pliometrik Antrenmanın 14-15 Yaş Grubu Basketbolcuların Dikey Sıçraması İle Bazı Fiziksel Ve Fizyolojik Parametreleri Üzerine Etkisi, 1995. Yüksek Lisans Tezi. Ankara: Gazi Üniversitesi Sağlık Bilimleri Enstitüsü; (Yrd. Doç. Dr. Kadir Gökdemir)

21. Ateş M, Ateşoğlu U, 2007. Pliometrik antrenmanın 16-18 yaş grubu erkek futbolcuların üst ve alt ekstremite kuvvet parametreleri üzerine etkisi. Spormetre Beden Eğitimi ve Spor Bilimleri Dergisi, 1, 21-28. 
22. Santos S, Jonatas F, Tomás H, 2015. Valenzuela, and Emerson F. Can different conditioning activities and rest intervals affect the acute performance of taekwondo turning kick. The Journal of Strength \& Conditioning Research 29, 1640-1647.

23. Sedaghat R, Mohammad HS, Asghar N, 2014. The impact of 8 weeks of plyometric exercises on anaerobic power, speed, and agility of male students. Advances in Environmental Biology, 3,410-414.

24. Sosa C, Lorenzo CA, Jiménez SL, Bonfanti N, 2014. Eccentric Exercise in Treatment of Patellar Tendinopathy in High Level Basketball Players. A Randomized Clinical Trial, Área de Investigación en Deporte, 23,456-468.

25. Ateşoğlu U.B. Kendi Vücut Ağırlığı ve Ek Ağırlıkla Yapılan Pliometrik Antrenmanın Bazı Fiziksel ve Fizyolojik Parametreler Üzerine Etkisi. 2002. Doktora Tezi. Ankara: Gazi üniversitesi; (Doç. Dr. A. Emre Erol).

26. Egana M, Done B. Physiological changes following a 12-week gym-based stairclimbing, elliptical trainer and treadmill running program in female. J Sports Med Phys Fitness, 2004 44: 141-146. 
Fatih Ahmet Genç, Önder Dağlıŏlu

EFFECT OF PLYOMETRIC TRAINING PROGRAM ON ATHLETIC

PERFORMANCE IN YOUNG TAEKWONDO ATHLETES

Creative Commons licensing terms

Authors will retain the copyright of their published articles agreeing that a Creative Commons Attribution 4.0 International License (CC BY 4.0) terms will be applied to their work. Under the terms of this license, no permission is required from the author(s) or publisher for members of the community to copy, distribute, transmit or adapt the article content, providing a proper, prominent and unambiguous attribution to the authors in a manner that makes clear that the materials are being reused under permission of a Creative Commons License. Views, opinions and conclusions expressed in this research article are views, opinions and conclusions of the author(s). Open Access Publishing Group and European Journal of Physical Education and Sport Science shall not be responsible or answerable for any loss, damage or liability caused in relation to/arising out of conflict of interests, copyright violations and inappropriate or inaccurate use of any kind content related or integrated on the research work. All the published works are meeting the Open Access Publishing requirements and can be freely accessed, shared, modified, distributed and used in educational, commercial and non-commercial purposes under a Creative Commons attribution 4.0 International License (CC BY 4.0). 